\title{
Politeness Communication of Officials in West Sumatra: Review of Principles of Politeness and Principles of Cooperation Perspective
}

\author{
Ermanto, Agustina, Emidar \\ Universitas Negeri Padang \\ Email: ermanto@fbs.unp.ac.id
}

\begin{abstract}
Government officials as public officials must use the Indonesian language in accordance with the principle of politeness and principles of cooperation. The purpose of this study was to express the performance of politeness using the Indonesian language orally by government officials of West Sumatra. The research data were 746 speeches (spoken) of government officials in West Sumatera, Indonesia, namely governor, vice governor, regent, and mayor who still held office in 2017. Data analysis technique was data identification that is determining politeness using Indonesian from the principle aspect of manners and principles of cooperation, data classification, data interpretation, and concluding. The research findings were the performance of the principle of courtesy of officials of West Sumatra is in accordance with the maxim of wisdom, the maxim of generosity, the maxim of praise, the maxim humility, the maxim of agreement, the maxim of sympathy. The findings on the performance of the principle of cooperation of officials of West Sumatra are in accordance with the maxim of quantity and manner, the maxim of quantity, quality, and manner, the maxim of relationships and ways, the maxim of the way. The performance speech of officials of West Sumatra in violation of the principle of cooperation that violates the maxim of quality and method and violate the maxim relationship.
\end{abstract}

Keywords-performance; Indonesian language; manners; cooperation

\section{INTRODUCTION}

The oral communication or written communication should be done by good and polite officials. If not properly done and polite, some of the negative possibilities that will happen are (1) the official will be humbled by the community, (2) the official is not appreciated by the community, (3) the message submitted by the officials is not effectively accepted by the community, 4) misplaced communication with the community, (5) communication noise, and so on. Based on the above, officials should carefully use the Indonesian language when communicating face-to-face with the public (and the media) or when communicating in writing or on social media.

The use of good Indonesian and polite is one of the good character and the soul of the Indonesian nation. The appreciation of the use of Indonesian language in communicating by officials in Indonesia is a form of appreciation for this nation's culture (see Law Number 24 of 2009 and Presidential Regulation Number 16/2010). If Indonesian is not appreciated and is not used well and politely, especially by officials, this nation's cultural decline will occur.

Research that examines the ethics and politeness of communicating by officials in Indonesia can also be described below. First, Corry W (2009, p. 14-18) has concluded that leaders should teach honesty in communication through transparent messages. Secondly, Rohali (2011, p. 76-97) studied language politeness and stated that there is a tendency of national character to negative character. Third, Yusri, Yuni Handayani, and Riskawati (2012, p. 116-122) found that the speech of the candidate for governor of South Sulawesi according to the maxim of propriety tended to follow the maxim of appreciation, maxim of simplicity. Fourth, Sosiowati (2013) examines politeness politician's language in the Talk Show on Metro TV and concludes by stating that the predicate is very polite, polite, well mannered, lack of polite, and impolite. Fifth, Mujianto (2013, p. 13-20) concludes that every stage of corruption simulator case investigation event experienced by state officials covering Polri, KPK, and president using different utterances, either speech function, mode, type, or speech strategy. Sixth, Pranowo (2015, p. 192-225) concluded that the intralingual and extralingual elements became the markers of the emergence of language.

Research on the communication of political figures officials in Indonesia has also become the attention of researchers. First, Setiana, Anggun; Munaris \& Muhammad Fuad (2015, p. 1-12) concluded that during the presidential debate from 2014-2019, Jokowi used repetition, hyperbolic, metaphorical, and personification style; variations of language in the form of official variety, effort, familiar, literature, idiolek, and sosiolek. Secondly, Asmara (2016, p. 379-388) concludes that the linguistic strategy of President Jokowi in instilling ideology and manifesto of government is done by utilizing the formal aspects of the text of his speech. Thirdly, Arofah (2015) concluded that political communicators use YouTube as an alternative medium for shaping positive images and influencing public opinion. Fourth, Sartini (2015, p. 171-179) states that language has tremendous power for political purposes and one of them is the Fifth Imagery, Widyawari (2016, p. 1-11) states that polite speech can facilitate the planting of ideology to other 
people. Sixth, Pusvita (2016, p. 861) states that the maxims and imperatives show that there is a balance of mindset and action with speech.

Indonesian language performance and politeness in communicating have become an important aspect for the success of officials in Indonesia. Good Indonesian-language performance in communicating by officials has been established by the Law of the Republic of Indonesia No. 24 of 2009 concerning Flags, Languages and State Symbols, and the National Anthem and Presidential Regulation of the Republic of Indonesia No. 16 of 2010 concerning the Use of Indonesian Language in Official Speeches President and / or Vice President and other Country Officials. The performance of using Indonesian language and politeness in communicating by officials is very important to embody the values of the character of the Indonesian nation as a polite nation because good and polite language performance will show a good and polite national culture as well.

What are the performance of the Indonesian language and the politeness of officials when communicating? This should be questioned because the condition of officials in Indonesia can change at a fast time. That is officials in Indonesia both executives, legislative, and many party leaders who took the position in a short time. With the condition of officials in Indonesia who generally carry out these positions in a short and unsustainable time, it will result in a poor condition in the performance of the use of Indonesian language and the politeness of the official's communication.

\section{METHODS}

This research is to qualitatively examine the performance of politeness communication between officials of West Sumatra Province. The sentence performance is viewed from the principle of manners and the principle of cooperation. To express the tendency of the two symptoms of politeness, explained by quantitative data. The research data is 746 oral sentences of government officials in West Sumatra, Indonesia, namely governors, deputy governors, regents, and mayors who are still in office in 2017. West Sumatra government officials are chosen by considering officials who have a lot of communication records on Youtube accounts. The source of the data is the recording of the oral speech of the government official obtained from Youtube. Data analysis techniques are the identification of data that determines the use of sentences from the principle aspects of courtesy and the principle of cooperation, data classification, data interpretation, and concluding.

\section{FINDINGS AND DISCUSSION}

\section{Findings}

Research findings on the performance of the use of politeness principles by executive officers of West Sumatra in oral communication can be stated as in table (1) below.

Table 1 Using The Principles of Politeness in Oral Communication

\begin{tabular}{llcc}
\hline Number & \multicolumn{1}{c}{ Aspects } & Amount of Data & Percentage \\
\hline 1 & $\begin{array}{l}\text { Speech in accordance with } \\
\text { the maximization of } \\
\text { wisdom }\end{array}$ & 39 & $5,2 \%$ \\
\hline 2 & $\begin{array}{l}\text { Speech in accordance with } \\
\text { the maximization of } \\
\text { generosity }\end{array}$ & 10 & $1,3 \%$ \\
\hline 3 & $\begin{array}{l}\text { Speech in accordance with } \\
\text { the maximization of praise }\end{array}$ & 67 & $9 \%$ \\
\hline 4 & $\begin{array}{l}\text { Speech in accordance with } \\
\text { the maximization of } \\
\text { humility }\end{array}$ & 123 & $16,5 \%$ \\
\hline 5 & $\begin{array}{l}\text { Speech in accordance with } \\
\text { the maximization of } \\
\text { agreement }\end{array}$ & 470 & $63 \%$ \\
\hline 6 & $\begin{array}{l}\text { Speech in accordance with } \\
\text { the maximization of } \\
\text { inference }\end{array}$ & 37 & $5 \%$ \\
\hline & Amount & 746 & $100 \%$ \\
\hline
\end{tabular}

Based on the table above, it can be argued that the performance of the principle of politeness by officials of West Sumatra in oral communication is (1) the speech according to the maxim of wisdom is as much as 39 speech (5.2\%); (2) the speech corresponding to the maxim of generosity is 10 speakers $(1.3 \%)$; (3) the speech corresponding to the maxim 
of praise is 67 speeches (9\%); (4) the speech corresponding to the maxim of humility is 123 speeches (16.5\%); (5) the speech according to the maxim of agreement is 470 speeches $(63 \%)$; (6) the speech corresponding to the maxim of inference is 37 speeches $(5 \%)$.

The findings of research on the performance of the principle of cooperation by officials of West Sumatra in oral communication can be presented as in table (2) below.

Table 2 Using The Principles of Cooperation in Oral Communication

\begin{tabular}{|c|c|c|c|}
\hline Number & Aspects & Amount of Data & Percentage \\
\hline 1 & $\begin{array}{l}\text { Speech in accordance with } \\
\text { the maximization quantity } \\
\text { and manner }\end{array}$ & 17 & 2,3 \\
\hline 2 & $\begin{array}{l}\text { Speech in accordance with } \\
\text { the maximization of } \\
\text { quantity, quality, and ways }\end{array}$ & 583 & 78,1 \\
\hline 3 & $\begin{array}{l}\text { Speech in accordance with } \\
\text { the maximization of } \\
\text { relationships and ways }\end{array}$ & 32 & 4,3 \\
\hline 4 & $\begin{array}{l}\text { Speech in accordance with } \\
\text { the maximization of } \\
\text { relationships and ways }\end{array}$ & 49 & 6,6 \\
\hline 5 & $\begin{array}{l}\text { Speech that violates the } \\
\text { maximization of } \\
\text { cooperation }\end{array}$ & 65 & 8,7 \\
\hline 6 & $\begin{array}{l}\text { Speech that violates the } \\
\text { maximization of quality } \\
\text { and ways }\end{array}$ & 61 & 8,2 \\
\hline \multirow[t]{2}{*}{7} & $\begin{array}{l}\text { Speech that violates the } \\
\text { maximization relationships }\end{array}$ & 4 & 0,5 \\
\hline & Amount & 746 & \\
\hline
\end{tabular}

Based on the above table, it can be stated that the performance of the use of the principle of cooperation by West Sumatra officials in oral communication is (1) speech that matches the maxim of quantity and method is 17 utterances $(2.3 \%)$; (2) utterances that are in accordance with the maxim of quantity, quality, and method are 583 utterances (78.1\%); (3) the appropriate speech with the maxim of relationship and manner is as much as 32 speech (4.3\%); (4) the speech according to the maxim of the way is 49 speeches $(6.6 \%)$; (5) speech breaking the maxim of cooperation is as much as 65 speech $(8.7 \%)$.

\section{Discussion}

Linguists like Leech (1993, p. 206-207) have put forward the principle of courtesy in communicating with six maxims. The six maxims of this courtesy principle are used as the basis for determining the speech as polite speech or impolite speech. So, the official communication data will be interpreted based on the six maxims stated by Leech (1993, p. 206-207). The performance of the West Sumatra executive's speech in oral communication is generally in accordance with the following politeness principles: (1) the maxim of wisdom is that the speaker tries to make as many others as possible; (2) the maxim of generosity that the speakers make the smallest possible profit and the greatest possible loss of self; (3) the maxim of praise that speakers try to praise others as much as possible; (4) the maxim of humility that speakers criticize themselves and try not to praise themselves; (5) the maxim of agreement that the speaker states, invites, create a common understanding in order to form an agreement; and (6) the maxim of conclusions that speakers express sympathy to others. The performances of this kind can be seen in the following example.

Example (1)

Dan jangan lupa bapak-bapak ibuk-ibuk jangan lupa bawa oleh-oleh sebagai tanda cinta kepada keluarga yang ditinggalkan. (data 119) 
Example (2)

Senang, bahagia nampak ceria, ketawa nah tentu kita juga ada menyiapkan persiapan untuk memberikan sesuatu ke Mesjid, kasih quran atau buku atau ada juga pohon-pohon yang kita ditanam yang berbuah dan sebagainya. (data 26)

Example (3)

Pertama, saya mau memberikan ungkapan salam kepada Pak Tafdir Rektor UNAND. (data 103) Example (4)

Example (5)

Selama ini belum satupun pejabat yang datang kecuali Bapak Gubernur

Jadi banyak hal ya yang mungkin perlu diangkat dalam diri kita dalam merefresing dan menyegarkan semangat Example (6) untuk bisa bekerja menjalankan amanat secara tuntas dan diselingi dengan hobi yang tadi. (data 15)

Kemudian sebulan sekali itu dengan motor cros atau .. itu juga mengunjungi beberapa daerah seperti bulan lalu kita ke Lubuk Alung misalnya. (Data 8)

Linguists such as Grice (Leech, 1993, p. 11-12) have put forward the principle of cooperation (PK) in communicating with the four maxims. If the speaker/speaker wishes to succeed in communicating should abide by or apply the principle of cooperation expressed by the Grice. Speech performance of executive officers of West Sumatra in oral communication in accordance with the principle of cooperation: (1) the maxim of quantity and manner because information is sufficient, informative, concise, and orderly; (2) the maxim of quantity, quality, and manner because the information is sufficient and informative, convincing and clear; (3) the maxim of relationships and the way because information is related to the topic and is stated concise, and orderly; (4) maximizing the method because the information is stated to be concise and orderly. The performance of the use of cooperation can be seen in the following example.

Example (7) Example (8)

Saya ini dulu waktu kuliah jualan buku, jualan kaos, baju dan sebagainya. (data 77)

UUD 45 pasal 31 ayat 3 ada kata-kata takwa, UU Sidiknas tentang pendidikan juga ada takwa, bahkan ikrar pegawai negri juga menjadi insan yang bertakwa dan banyak digunakan. (data 212)

\section{Example (9)}

Walaupun tadi pagi sebagai Gubernur kami diminta oleh WAT inpres menjadi narasumber di depan para Example (10) dewan pertimbangan Presiden untuk menyampaiakan tentang reformasi birokrasi. (data 110)

Selama ini belum satupun pejabat yang datang kecuali Bapak Gubernur bahkan Bapak Bupatipun belum pernah datang, kan gitu kan. (data 24)

Another fact is that the executive speech of West Sumatra in oral communication was also found in a speech violating Grice's cooperation principle (Leech 1993, p. 11-12). Speeches that violate the principle of cooperation can be grouped as follows: (1) speech that violates the maxim of quality and method is 61 speeches $(8.2 \%)$; (2) loans that violate the maximal relationship are 4 utterances $(0.5 \%)$.

The speech performance of the executive officers of West Sumatra in verbal communication that violates the principle of cooperation, in particular, violates the maxim of quality and the way because information is less convincing and vague can be seen in the following example.

Example (11)

Sumber uang kita punya. (data 440)

The performance of the West Sumatra official's speech in oral communication that violates the principle of cooperation, in particular, violates the maxim of the relationship because information is not related to the topic can be seen in the following example.

\section{Example (12)}

Bapak-ibuk yang saya hormati, tentu hadirin bapak-ibuk setidaknya juga kami tawarkan untuk beriwisata. (data 118)

Based on the above findings, it can be stated that the performance of politeness speech by West Sumatra officials in oral communication reflects language politeness especially in accordance with the maxim of agreement $(63 \%)$ and 
the maxim of humility (16.5\%). This is in accordance with the culture of the Minangkabau people who adhere to the four rules of communication called the kato nan ampek (four perspectives of communication). The findings of this study support the findings of Yusri, Yuni Handayani, and Riskawati's research (2012, p. 116-122), the findings of Sosiowati's research (2013), the findings of Widyawari (2016, p. 1-11), and the findings of Pusvita's research (2016, p. 861) that officials in Indonesia has politeness in good language in accordance with the principle of courtesy and in accordance with the principle of cooperation.

\section{CONCLUSION}

Based on the results and discussion in the description above, the following is concluded. First, it was found that government officials of West Sumatra have applied the principle of manners in communicating. From the principle aspect of courtesy, found (1) the speech corresponding to the maxim of wisdom (5.2\%); (2) speech corresponding to the generosity maxim $(1.3 \%)$; (3) the speech corresponding to the maxim of praise $(9 \%)$; (4) the speech corresponding to the maxim of humility $(16.5 \%)$; (5) speech in accordance with the maxim of agreement (63\%); (6) the speech corresponding to the maxim of inference $(5 \%)$.

Second, it is found that there are still government officials of West Sumatra who violate the principle of cooperation in communicating. From the aspect of cooperation principle, found (1) speech according to the maxim of quantity and manner $(2,3 \%)$; (2) speech in accordance with the maxim of quantity, quality and method (78.1\%); (3) a speech that corresponds to the maxim of relationships and ways (4.3\%); (4) the corresponding speech to the maxim way $(6.6 \%)$. In addition, there were also found speech violating cooperative maxims $(8.7 \%)$. Speech performance of government officials of West Sumatra in violation of the principle of cooperation can be grouped below: (1) speech violating the maxim of quality and method $(8.2 \%)$; (2) a speech breaking the maxim of the relationship $(0.5 \%)$.

\section{References}

Arofah, K. (2015). Youtube as media clarification and statement of political figure. Journal of communication science, Volume 13, Number 2, May-August 2015, p. 111-123.

Asmara, R. (2016). President jokowi's linguistic strategy in instilling ideology and government manifesto. LITERA, Volume 15, Number 2, October 2016 p. 379-388.

Corry W, A. (2009). Ethics communicates in the delivery of aspirations. Journal of Communication of Tarumanagara University, Year I / 01/2009 p. 14-18.

Leech, G. (1993). Pragmatic principles. Jakarta: University of Indonesia Publisher.

Mujianto, B. (2013). Speech of state officials in the news "corruption" in mass media print. JOURNAL HUMANITY, 8 , March 2, 2013 p. 13 - 20.

Pranowo. (2015). Intralingual and extralingual elements as markers of language power and language values in political communication. Journal of Adabiyyāt, Vol. XIV, No. 2, December 2015 p. 192-225.

Pusvita, W. D. (2016). Maksim and imperative politeness in the eyes of najwa episode "habibi today" (a pragmatic study). Proceedings of the International Seminar on Inscription III.

Rohali. (2011). Chartered speech as a character education pillar: sociopragmatic perspective. Character Education Journal, Year I, Number 1, October 2011 p. 76 -97.

Sartini, N. W. (2015). Language and imagery: linguistic strategies in political discourse. JURNAL TUTUR Vol.1, August 2, 2015 p. 171-179.

Setiana, A.; Munaris \& M. Fuad. (2015). Linguistic aspects of Jokowi on presidential candidate debate and its usability in learning. Journal of Words (Language, Literature and Learning) April 2015 Indonesian Language and Literature Education Program FKIP Universitas Lampung, p. 1-12.

Sosiowati, IGAG. (2013). Political language persuasion in the talk show on metro tv". Dissertation of Doctoral Program of Linguistics Program of Postgraduate Program, Udayana University Denpasar.

Law of the Republic of Indonesia Number 24 the Year 2009 regarding Flag, Language, And State Coat, And National Anthem.

Widyawari, CPGM. (2016). Representation of ideology in speech in the compassion of state officials at mata najwa talk show. Seloka: Indonesian Language and Literature Education Journal SelOKA 5 (1) (2016), p. 1-11.

Yusri, Y.H., \& Riskawati. (2016). Representation of acts of speech for candidates of the governor of south sulawesi: discourse analysis of political discourse. MAKARA, SOCIAL HUMANIORA, VOL. 16, NO. 2, DECEMBER 2012, p. 116-122. 